\title{
Kinesiske investorer ignorerer Danmark
}

Af Martin Marcussen

Det lykkes ikke for Danmark at tiltrække investeringer fra Kina. Vi har ellers gjort meget ud af at skabe rigtig gode politiske relationer til netop Kina. Derimod klarer Norge sig fint. Kineserne vil gerne investere i Norge på trods af, at der i flere år nærmest ingen politiske relationer har været mellem de to lande.

I finansielle kredse er det ikke gået ubemærket hen, at Kinas investeringer i udlandet nu overstiger udlandets investeringer i Kina (figur 1). Det er en proces, der er gået stærkt - ikke mindst siden 2001 hvor Kina blev medlem af Verdenshandelsorganisationen WTO.

Faktisk er Kina blevet en så stor og betydelig investor på globalt plan, at Kinas udenlandske investeringer nu kun overgås af USA (figur 2).

I en første fase forsøgte de statsejede virksomheder - stærkt tilskyndet af partitoppen og investeringsvillige statsbanker - at erobre nye markeder, herunder at sikre sig adgang til de råvarer og ressourcer, som den kinesi- ske industriproduktion er så afhængig af. Senere bredte investeringerne sig også til andre regioner i verden med henblik på at skaffe sig adgang til nye teknologier inden for alle mulige områder. Nogle af disse teknologier kunne tilpasses det kinesiske hjemmemarked. Andre kunne videresælges til lande, der befinder sig længere tilbage end Kina i den teknologiske udvikling.

Senere blev målet for de kinesiske investeringer i udlandet underholdningsindustrien, almindelige forbrugsgoder og ejendomsmarkedet. I dag dækker de kinesiske industrier et bredt spektrum af sektorer i de moderne økonomier.

Med finanskrisens udbrud tog Kinas investeringer i EU også for alvor fart. Det europæiske erhvervsliv var i desperat kapitalmangel, og kinesiske statsejede virksomheder benyttede lejligheden til at købe stort ind for billige penge. Der blev investeret så meget i EU, at Kinas investeringer i de 28 medlemslande fra 2016 oversteg det samlede EU's investeringer i Kina. 


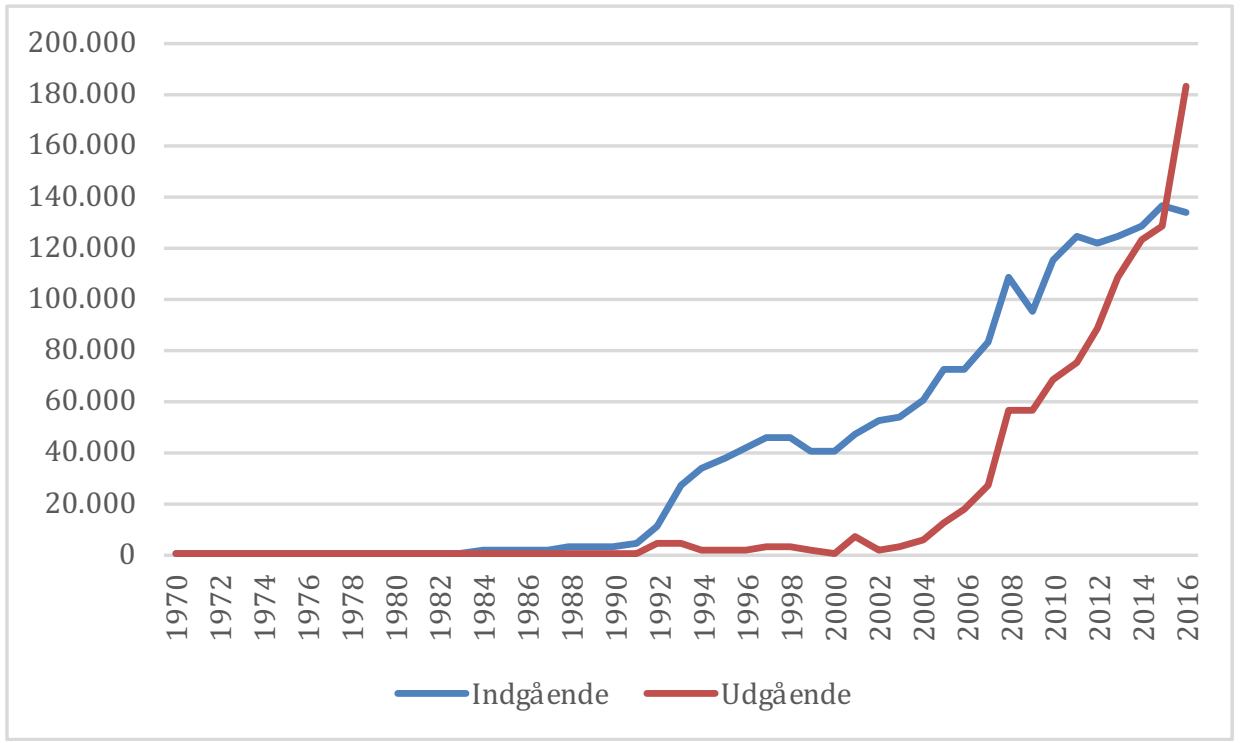

FIGUR 1: Årlige investeringsstrømme ind og ud af Kina, 1970-2016, millioner USD

Kilde: http://unctadstat.unctad.org/

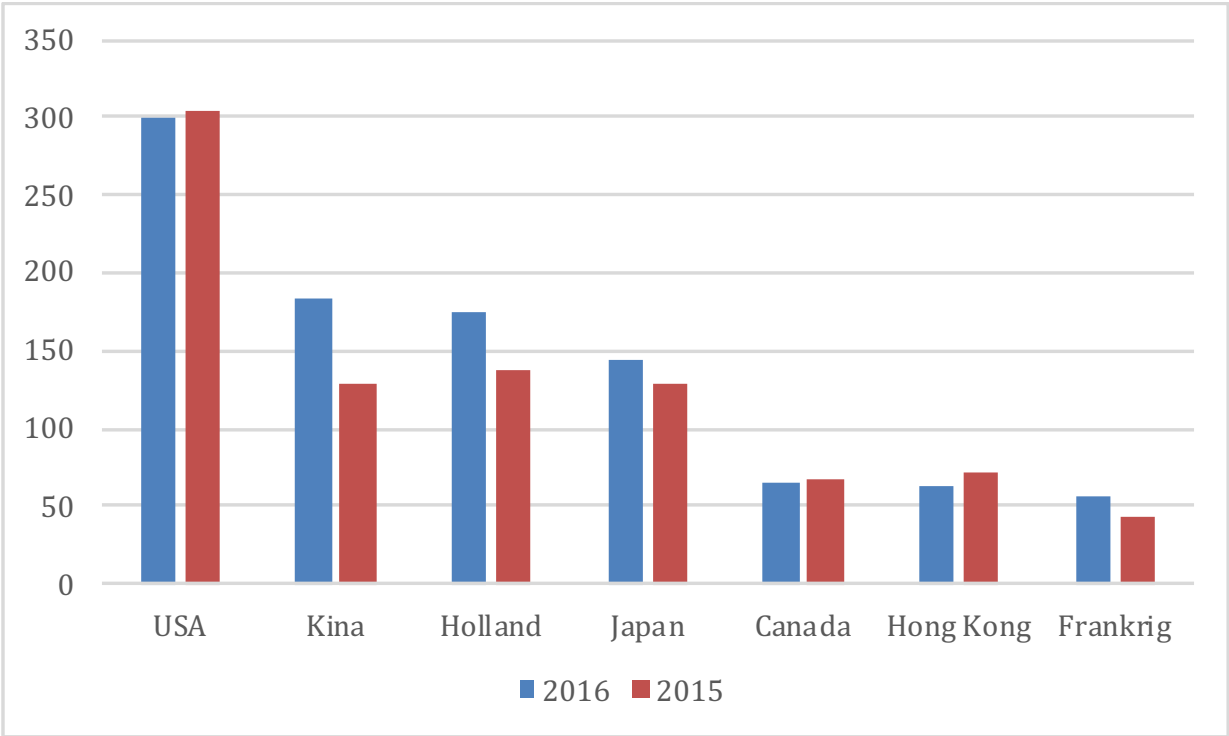

FIGUR 2: Udgående investeringer 2015 og 2016, milliarder \$ dollars

Kilde: UNCTAD [2017: 14]. 
De kinesiske investeringer i EU lader dog til at være noget ulige fordelt mellem medlemslandene (figur $3)$. Langt de største kinesiske investeringer foretages i Storbritannien, Tyskland, Italien og Frankrig.

Det fremgår også med al ønskelig tydelighed, at Danmark hører til blandt de lande i EU, der modtager allerfærrest investeringer fra Kina. Danmark kan for eksempel slet ikke konkurrere med Sverige og Holland på denne parameter.

\section{Investeringsgabet vokser og vokser}

Danmark har i det hele taget et stort og vedvarende problem med at tiltrække internationale investeringer. Skiftende danske regeringer har ellers haft det som en eksplicit målsætning, at Danmark skal høre til blandt de lande i verden, der tiltrækker flest internationale investeringer.

I det seneste regeringsgrundlag står eksempelvis, at "Regeringen ønsker, at Danmark skal være et attraktivt land at investere i, og vi vil arbejde for at tiltrække flere udenlandske investeringer. Danmark skal være rustet til den hårde internationale konkurrence, både herhjemme og ude i verden" (Regeringen (2016), 'For et friere, rigere og mere trygt Danmark').

Internationale investeringer tilvejebringer kapital, der kan investeres i ny produktionsinfrastruktur. De skaber også arbejdspladser og giver skatteindtægter. Og investeringer udefra kan være med til at tilføre Danmark ny inspiration via ny arbejdskraft, ny ledelse, og nye teknologier. I den offentlige debat er der næsten kun gode ting at sige om udenlandske investeringer $\mathrm{i}$ Danmark.

På trods af at Danmark i rigtig mange år har ligget helt $i$ toppen af Verdensbankens 'Ease of Doing Business Index' 2018, går det ikke så

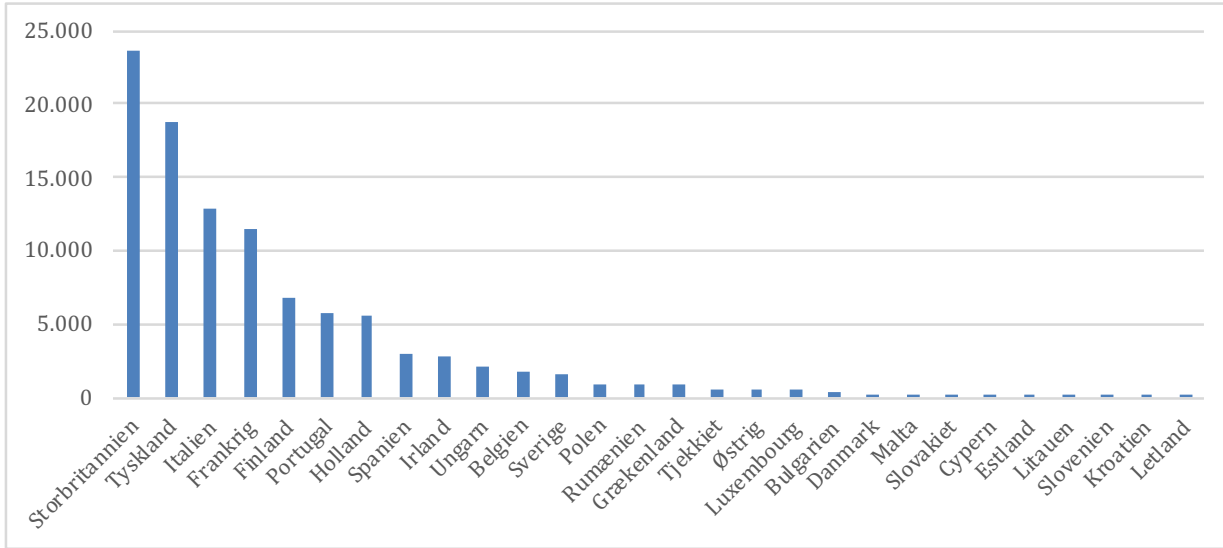

FIGUR 3: Kinesiske investeringer i EU-28, 2000-2016, millioner euro. 
godt med at tiltrække investeringer, til landet (figur 4). Investeringsgabet, det vil sige differencen mellem de investeringer, danske erhvervsvirksomheder laver i udlandet, og de tilsvarende investeringer, som udenlandske erhvervsvirksomheder laver i Danmark, bliver bare større og større for hvert år der går.

Udenrigsministeriet arbejder hårdt på sagen. Her er det InvestinDenmark, der har fået til opgave at overbevise udenlandske investorer om at placere deres penge $\mathrm{i}$ Danmark.

InvestinDenmark arbejder med udgangspunkt fra Asiatisk Plads, og med specialiserede ansatte placeret rundt omkring på de mest lovende markeder. Under overskriften 'Why
Denmark' fremgår blandt andet, at der ikke er korruption i Danmark; at man med udgangspunkt i Danmark kan nå hele det europæiske marked; at vi har et fleksibelt arbejdsmarked med en højtuddannet arbejdskraft; at vi tilbyder understøttende institutionelle rammer og lav virksomhedsskat; at vi især er dygtige inden for sundheds-, miljø- og klimaområderne; at der er gode internet- og flyforbindelser; og at Danmark i det hele taget er et godt land at leve $\mathrm{i}$.

Men lige meget hjælper det. Ingen gode argumenter kan tilsyneladende overbevise de investeringsvillige kinesere om at kigge $i$ retning af Danmark.

Danmark har ellers ikke ligget på den lade side for så vidt angår in-

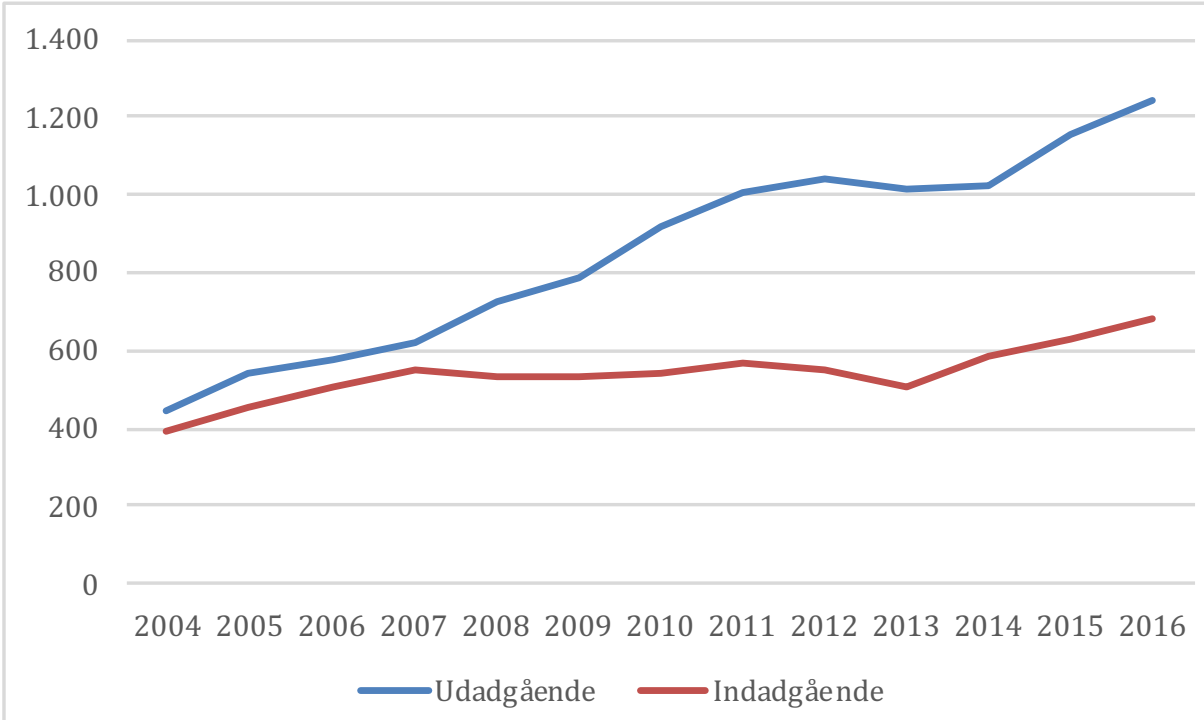

FIGUR 4: Investeringsgabet: Beholdning af udenlandske investeringer, ind og ud af Danmark, 2004-2016, mia. kr. 


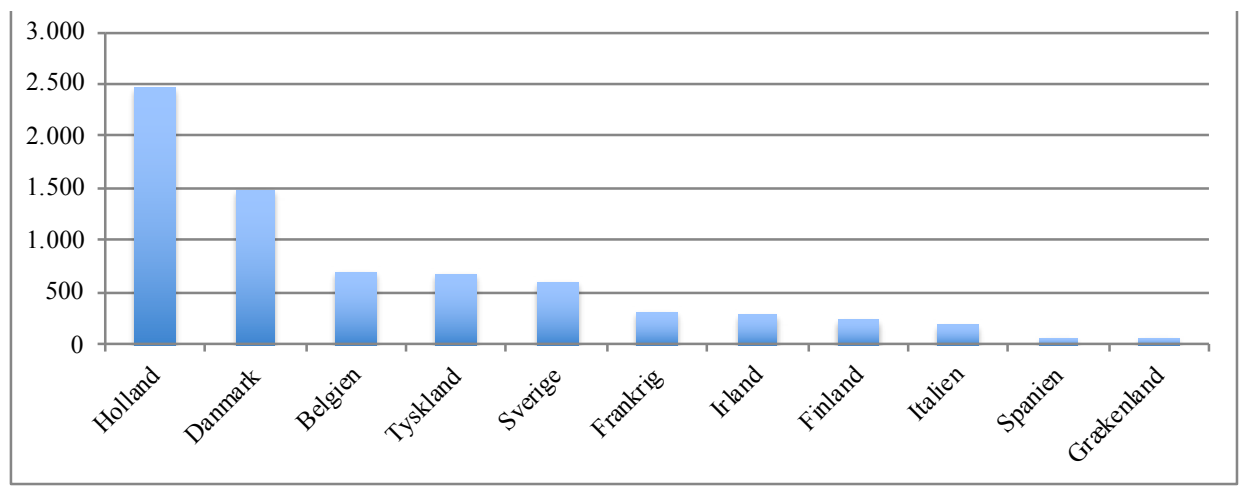

FIGUR 5: Investeringer i Kina fra udvalgte EU-lande, opgjort per indbygger i euro (2013)

Kilde: Udenrigsministeriet [2015: 9].

vesteringer rettet mod Kina, tværtimod. Danske multinationale virksomheder har i årevis investeret massivt i Kina. Faktisk så meget, at kun Holland overgår Danmark opgjort i investeringsvolumen per indbygger (figur 5).

Alligevel har relationen mellem Kina og Danmark i mange år været karakteriseret af et stort handelsunderskud og et endnu større investeringsgab i kinesernes favør. Det lader med andre ord til, at vi har ganske vanskeligt ved at hægte os på det kinesiske vækstlokomotiv.

\section{På god fod}

Den danske tilgang til Kina synes i al almindelighed at være, at vi først og fremmest bør satse på at tilvejebringe gode politiske relationer med kineserne. Der har godt nok været nogle små sammenstød undervejs - i de senere år mest i relation til Tibets åndelige leder Dalai Lamas tilbagevendende besøg i Danmark. Men det har vi nu fundet en løsning på. I en verbalnote fra 2009 har regeringen lovet Kina at modsætte sig Tibets uafhængighed. Og siden er det gået slag i slag.

Som en manifestation af det gode dansk-kinesiske forhold blev der eksempelvis i 2008 underskrevet et såkaldt omfattende strategisk partnerskab mellem de to lande. Et partnerskab der blev udvidet i 2015. I dag har 47 lande i verden etableret lignende strategiske partnerskaber med Kina. Man kan sågar tale om et kinesisk partnerskabsdiplomati (Zhongping og Jing, 2014).

På baggrund af partnerskaberne bliver der udarbejdet detaljerede handlingsplaner med mål for udviklingen af det dansk-kinesiske samarbejde inden for en lang række områder, især 
de økonomiske. Man lover hinanden, at man vil uddybe alle former for $ø$ konomiske relationer mellem de to lande, inklusive at fremme de grænseoverskridende investeringer i begge retninger.

Selvom Kinas strategiske partnerskaber er forskellige fra land til land, er der alligevel én ting, der går igen $i$ dem alle, nemlig en eksplicit forpligtelse for de underskrivende parter om at undlade at intervenere $\mathrm{i}$ hinandens indre anliggender. I partnerskaberne anerkender parterne, at de hver især har forskellige syn på demokrati og menneskerettigheder, og at der i øvrigt findes forskellige veje til fremskridt. Hvis man er parat til at skrive under på dette, lover Kina til gengæld at indgå $\mathrm{i}$ en dialog om menneskerettigheder og demokrati.

Som en følge heraf afholder Danmark sig fra at bruge et såkaldt megafon-diplomati i Kina. I store træk overdrages opgaven med at fremme menneskerettighedssituationen i Kina til EU-delegationen i Beijing og vore nabolande. Og der er ellers nok at tage fat på. Det seneste EIU Democracy Index placerer Kina på en 139. plads ud af 164 lande. Det konkluderes, at Kina er et autoritært og ufrit regime, og at demokratiets tilstand er for nedadgående.

Ud over det omfattende og udvidede strategiske partnerskab er der flere andre eksempler på, at det politiske forhold mellem Danmark har nået et all-time high. Danmark er eksempelvis sammen med kun 24 andre lande i verden blevet medlem af den såkaldte Pandaklub. I Europa er foruden Dan- mark også Belgien, Finland, Frankrig, Holland, Storbritannien, Tyskland og Østrig med i den eksklusive klub. Pandaer udlånes til lande, som Kina føler man, at har en helt særlig relation til.

Vi har endvidere også, sammen med 140 andre lande i verden, været imødekommende i forhold til Kinas udbredelse af de såkaldte Confuciusinstitutter. De er typisk placeret på én af de højere læreranstalter - i Danmark er det Copenhagen Business School, Aalborg Universitet og Musikkonservatoriet. Delvist finansieret af det kinesiske undervisningsministerium er formålet at undervise og forske i kinesisk sprog, historie og kultur.

Danmark har desuden forankret relationen til Kina gennem etableringen af venskabsbyer. Der er i øjeblikket ni venskabsby-aftaler mellem danske og kinesiske byer/regioner. Det varierer fra aftale til aftale, hvad de i praksis bruges til, og hvor ofte.

Endelig, hvilket er en særdeles vigtig markør på det udmærkede politiske samarbejde mellem vore to lande, er antallet af højniveaubesøg mellem de to lande nærmest eksploderet. Næst efter EU-møderne i Bruxelles synes danske ministres og embedsmænds besøg i Kina at være de mest hyppige.

Det kinesiske udenrigsministerium forsøger at registrere samtlige disse indgående højniveaubesøg, og på dets hjemmeside kan man regne sig frem til, at der i perioden 2001-2017 har været afviklet i alt 83 danske højniveaubesøg i Kina. Hele 62 af disse er afviklet inden for de seneste otte år.

Litteraturen om og de officielle beskrivelser af de politiske relationer 
mellem Danmark og Kina er entydig: de har aldrig været bedre. Men på hvilke måder kan det tænkes, at gode politiske relationer kan fremme kinesernes lyst til at investere i Danmark?

Man må formode, at ræsonnementet har været, at adgangen til kinesernes bugnende lagre af investeringskapital går gennem det politiske system.

Det lyder umiddelbart helt rigtigt. Den kinesiske økonomi er statsstyret. Det er hovedsageligt statsejede virksomheder, der foretager investeringer i udlandet; det er partiet, der fremlægger en flerårig investeringsstrategi; og det er statsbanker, der stiller den risikovillige kapital til rådighed.

Det er tilsvarende kendt, at den kinesiske form for netværksopbygning

\section{Man må formode, at ræsonnementet har været, at adgangen til kinesernes bugnende lagre af investeringskapital går gennem det politiske system.}

og tillidsskabelse, Guanxi, tager tid meget lang tid - og tager sit udgangspunkt i personlige relationer på højt niveau, og desuden indeholder forsikringer om, at ingen af parterne taber ansigt. Idéen er så den, at disse tillidsrelationer åbner døre rundt omkring i den kinesiske økonomi og helt ud i den yderste afkrog af det store land.

Med udgangspunkt i dette ræsonnement giver det rigtig god mening, at danske diplomater og lange karavaner af ministre, embedsmænd og medlemmer af kongehuset slår turen omkring Kina. Det giver også rigtig god mening, at vi i Danmark gør vores bedste for at imødekomme de ønsker, som de kinesiske delegationer måtte have i forbindelse med deres besøg i Danmark.

\section{Hvad med Norge?}

I Danmark vil man for alt i verden undgå at komme i en situation, som den Norge befinder sig i. Siden den norske Nobelkomite tildelte den fængslede kinesiske dissident Liu Xiaobo en fredspris i 2010 og viste verden en symboltung tom stol i Oslo rådhus, har al politisk kontakt mellem Kina og Norge været afbrudt. En bilateral handelsaftale, som var i færd med at blive færdigforhandlet, blev lagt på is. Den årlige menneskerettighedsdialog mellem Norge og Kina, som havde fundet sted siden 1997, blev aflyst.

Norge er da heller ikke blevet tilbudt en plads i Pandaklubben, og der er kun ét Confuciusinstitut $i$ landet. I perioden 2001-17 har det kinesiske udenrigsministerium registreret 42 indgående højniveaubes $ø g$ fra Norge, hvoraf de fleste er afviklet før 2011. I seks år (2011-2016) var der kun fem norske højniveaubesøg i Kina. Norge er desuden det land i Norden, der har færrest venskabsbyaftaler med Kina. I diplomatiske kredse taler man om den norske istid. Nordmændene er blevet frosset ud af kineserne.

Alligevel er det i denne artikels optik særdeles interessant at sammenligne den norske situation med den danske. Det viser sig nemlig, at kineserne, på trods af den norske istid, ikke har det mindste imod at investere i Norge. Siden 2008 er kinesernes 
TABEL 1: Kinas investeringsaktivitet i Norge, Danmark, Sverige og Holland, 2005-2017

\begin{tabular}{|c|c|c|c|c|c|c|}
\hline År & Måned & $\begin{array}{l}\text { Kinesisk } \\
\text { investor }\end{array}$ & $\begin{array}{l}\text { Beløb } \\
\text { (mio. USD) }\end{array}$ & Andel & Investeringsmål & Sektor \\
\hline \multicolumn{7}{|c|}{ NORGE } \\
\hline 2008 & Juli & CNOOC & $\$ 2.490$ & $100 \%$ & Awilco Offshore & Energi, Olie \\
\hline 2011 & Januar & ChemChina & $\$ 2.010$ & $100 \%$ & Elkem & Kemikalier \\
\hline 2014 & November & ChemChina & $\$ 640$ & $100 \%$ & REC Solar ASA & Solenergi \\
\hline 2016 & Juli & $\begin{array}{l}\text { Qihoo and } \\
\text { Beijing Kunlun }\end{array}$ & $\$ 610$ & & Opera Software & Telecom \\
\hline 2009 & November & Huawei & $\$ 180$ & & Telenor & Telecom \\
\hline 2013 & Oktober & $\begin{array}{l}\text { Sichuan } \\
\text { Railway } \\
\text { Industry }\end{array}$ & $\$ 130$ & $27 \%$ & & Biler \\
\hline \multirow[t]{2}{*}{2016} & Januar & Reignwood & $\$ 110$ & $51 \%$ & Voss & Forbrug \\
\hline & & & $\$ 6.170$ & & & \\
\hline \multicolumn{7}{|c|}{ DANMARK } \\
\hline 2013 & Oktober & Huawei & $\$ 700$ & & TDC & Telecom \\
\hline 2017 & Maj & Geely Auto & $\$ 390$ & $26 \%$ & Saxo Bank & Bank \\
\hline \multirow[t]{2}{*}{2017} & Oktober & Geely Auto & $\$ 320$ & $22 \%$ & Saxo Bank & Bank \\
\hline & & & $\$ 1.410$ & & & \\
\hline \multicolumn{7}{|c|}{ HOLLAND } \\
\hline 2016 & June & \begin{tabular}{|l} 
CIC and Wise \\
Road Capital
\end{tabular} & $\$ 2.750$ & & NXP Semi & Teknologi \\
\hline 2014 & Februar & COFCO & $\$ 2.040$ & $51 \%$ & Nidera & Landbrug \\
\hline 2015 & Maj & CIC & $\$ 1.800$ & $100 \%$ & RF Power Units & Technology \\
\hline 2015 & Februar & Anbang & $\$ 1.670$ & $100 \%$ & Vivat & Finans \\
\hline 2016 & August & cosco & $\$ 1.440$ & $49 \%$ & Nidera & Landbrug \\
\hline 2016 & Oktober & Anbang & $\$ 560$ & & Blackstone & Ejendomme \\
\hline 2010 & December & Sinochem & $\$ 270$ & $50 \%$ & DSM & Medicin \\
\hline 2011 & Juni & BAIC & $\$ 270$ & $100 \%$ & $\begin{array}{l}\text { Inalfa Roof } \\
\text { Systems }\end{array}$ & Biler \\
\hline 2007 & Juni & $\begin{array}{l}\text { China Ocean } \\
\text { Shipping }\end{array}$ & $\$ 140$ & $80 \%$ & Burg Industries & Shipping \\
\hline 2016 & Maj & $\begin{array}{l}\text { China Ocean } \\
\text { Shipping }\end{array}$ & $\$ 140$ & $35 \%$ & $\begin{array}{l}\text { Euromax } \\
\text { Terminal } \\
\text { Rotterdam }\end{array}$ & Logistik \\
\hline \multirow[t]{2}{*}{2006} & December & $\begin{array}{l}\text { Sichuan } \\
\text { Changhong }\end{array}$ & $\$ 100$ & $75 \%$ & $\begin{array}{l}\text { Sterope } \\
\text { investments }\end{array}$ & Finans \\
\hline & & & $\$ 11.180$ & & & \\
\hline
\end{tabular}

\section{SVERIGE}

\begin{tabular}{|c|c|c|c|c|c|c|}
\hline 2017 & December & Geely Auto & $\$ 3.270$ & $8 \%$ & Volvo Trucks & Biler \\
\hline 2010 & Marts & Geely Auto & $\$ 2.700$ & $100 \%$ & Volvo & Biler \\
\hline 2015 & Juli & $\begin{array}{l}\text { China } \\
\text { Minsheng } \\
\text { Investment }\end{array}$ & $\$ 2.200$ & $100 \%$ & $\begin{array}{l}\text { Sirius } \\
\text { International } \\
\text { Insurance }\end{array}$ & Finans \\
\hline 2017 & Januar & Dalian Wanda & $\$ 960$ & $100 \%$ & Nordic Cinema & Underholdning \\
\hline 2017 & December & Tencent & $\$ 800$ & & Spotify & Underholdning \\
\hline \multirow[t]{2}{*}{2017} & September & HNA & $\$ 140$ & $19 \%$ & Rezidor & Turisme \\
\hline & & & $\$ 10.070$ & & & \\
\hline
\end{tabular}


investeringer i Norge skudt i vejret. Fredsprisen til Liu Xiaobo i 2010 lader ikke til at have lagt nogen som helst dæmper på kinesernes investeringslyst. Kinesernes investeringer i Norge i tidsrummet 2005-2017 udgør over seks milliarder amerikanske dollars. Det betyder, at Norge er et af de lande i Norden, hvor kineserne ejer allermest (tabel 1).

Det fremgår blandt andet, at Kina investerer et beløb svarende til 14 mia. danske kroner for at købe kemikalievirksomheden Elkem af Orkla bare to måneder efter overrækkelsen af den famøse fredspris. Det fremgår desuden, at både Holland og Sverige er godt inde i varmen, og det på trods af, at især Sverige med den feministiske udenrigspolitik ikke har forspildt en chance for at promovere sine synspunkter på menneskerettighedsområdet.

Den efterhånden brede litteratur om Kinas internationale investeringer giver ikke anledning til at formode, at gode politiske relationer indgår i de overvejelser de kinesiske myndigheder har i udarbejdelsen af deres investeringsstrategi.

Det viser sig, at kinesernes investeringer i Europa følger helt konventionelle modeller. Kinesernes investeringsmønstre er med andre ord helt parallelle med de mønstre, som vi kender fra alle mulige andre internationale investorer. Litteraturen går så langt som til at advare mod at betragte kinesiske investorer med et andet sæt parametre end dem, vi normalt anven- der i analysen af internationale kapitalstrømme. Erfaringen og forskningen tilsiger kort sagt, at man ikke kan smigre og sleske sig til investeringer fra kineserne. At det forholder sig på den måde, understøttes tilsyneladende af det norske og danske eksempel.

\section{Bekymrede miner}

Set i lyset af Danmarks generelt ringe tiltrækningskraft for så vidt angår internationale investeringer, er det måske en ringe trøst, at de lande, der hidtil har modtaget den største del af de kinesiske investeringer i Europa, nu er begyndt at få bekymrede miner.

Bekymringen skyldes flere forhold. Kan det eksempelvis tænkes, at meget store kinesiske investeringer også betyder, at kineserne dermed får indflydelse på et lands politik og økonomi? En anden bekymring går på, om det nu også er fornuftigt at sælge ud af et lands ypperligste teknologi? Det er trods alt tale om teknologier, der har kostet en god mængde ressourcer at udvikle og forfine, og som overdrages til en mulig konkurrent.

En tredje bekymring handler om, at kineserne i nogle tilfælde ønsker at købe sig ind på områder og i sektorer, der vedrører et lands kritiske infrastruktur, og som på mange måder har med landets generelle 
sikkerhed og forsvarsevne at gøre. Bekymringen kan for det fjerde også vedrøre spørgsmålet om kinesernes evne og lyst til at sikre europæiske arbejdstageres rettigheder. De europæiske arbejdsmarkedsmodeller kan være i farezonen.

Endelig kan jagten på kinesiske investeringer betyde, at de europæiske lande indgår i en ufrugtbar gensidig konkurrence om at tilbyde de mest fordelagtige vilkår.

Lige præcis disse bekymringer lå formanden for Europa-Kommissionen, Jean-Claude Juncker, på sinde, da han den 13. september 2017 gav sin State of the Union tale til Europa-Parlamentet:

"Let me say once and for all: we are not naïve free traders. Europe must always defend its strategic interests. This is why today we are proposing a new EU framework for investment screening. If a foreign, state-owned, company wants to purchase a European harbour, part of our energy infrastructure or a defence technology firm, this should only happen in transparency, with scrutiny and debate. It is a political responsibility to know what is going on in our own backyard so that we can protect our collective security if needed."

Hvilke eksempler han konkret havde i tankerne er vanskeligt at sige noget præcist om, men det kan være kinesernes overtagelse af havnen i Piræus, Grækenland over en 35-års periode for den nette sum af $32 \mathrm{mia}$. kroner. Det kan også være kinesernes bud på en aktiepost i Athens internationale lufthavn, han har i tan- kerne, eller det forhold at kinesiske investorer har vist interesse for at overtage et græsk jernbaneselskab.

\section{Fælles screeningsmekanisme}

I det hele taget har Kina ikke ligget på den lade side, mens der var finanskrise, og indkøbspriserne var lave i Europa. Det gælder også den kritiske infrastruktur i Portugal, hvor Kina har købt 21 pct. af aktierne i elselskabet EDP for 19,6 mia. kr. og 25 pct. af aktierne i eldistributionsselskabet REN for 2,9 mia. $\mathrm{kr}$.

Det er måske i lyset af disse og mange andre eksempler, at Juncker $ø$ nsker sig en europæisk investeringsscreeningsmekanisme, der kan tages i anvendelse, når man skal vurdere, om en udefrakommende investering på nogen tænkelig måde kan være i konflikt med europæiske strategiske interesser. En tilsvarende mekanisme har man gode erfaringer med i blandt andet Australien og Canada, hvor kineserne har købt stort ind på råstofområdet.

Danmark har foreløbigt meddelt, at man ikke agter at støtte et initiativ til en fælles europæisk screeningsmekanisme. Tværtimod er politikken den, at Danmark principielt ønsker at støtte frie globale kapital- og varebevægelser og dermed også hindre, at barrierer for den frie bevægelighed etableres. Det er et standpunkt, som skiftende kinesiske ambassadører i Danmark roser ved enhver given lejlighed. I Danmark mener vi, at vi selv er i stand til at vurdere, hvornår en foreslået investering er eller ikke er overensstemmelse med vore nationale interesser. 
Med erfaring fra de få investeringer, som kineserne indtil videre har $ø$ nsket at placere i Danmark, kan det konstateres, at det ikke umiddelbart blev vurderet at være et problem, at Huawei købte sig ind i TDC i 2013.
I et forsøg på ikke at fornærme kineserne blev der hurtigt opfundet en begrundelse for, at det slidte og nedrivningsklare Grønnedal alligevel ikke var til salg.

Grønnedal skulle nu pludselig være et strategisk og logistisk støttepunkt for Forsvaret. Det skal anvendes dels til oplægning af brændstof, opbevaring af havmiljøbekæmpelsesmateriel med videre, dels til øvelses- og uddan-

Dette på trods af at den amerikanske kongres året før havde advaret om, at netop Huawei bedrev forskellige former for spionageaktivitet. Det er siden blevet besluttet, at Center for Cyber Security løbende skal overvåge Huaweis aktiviteter i Danmark.

Ét eneste eksempel viser, at Danmark faktisk kan sige nej tak til investeringer, som vi vurderer er i konflikt med vore strategiske og sikkerhedspolitiske interesser.

I 2016 besluttede statsminister Lars Løkke Rasmussen således at fastholde den ellers nedlagte flådestation Grønnedal på Grønland på danske hænder. Den danske regering havde ellers i flere år forsøgt at sælge netop Grønnedal med den klausul, at køberen skulle rydde op efter mange års olieforurening.

Kina havde i nogle år vist interesse for det arktiske område, og $\mathrm{i}$ 2013, med velvillig dansk støtte, fik Kina observatørstatus i Arktisk Råd. $\mathrm{Nu}$ var kineserne så villige til at gå skridtet videre og købe Grønnedal. nelsesformål. Derudover kan Grønnedal stilles til rådighed for øvrige myndigheders opgaveløsning i det arktiske område, eksempelvis civile forskningsaktiviteter.

\section{Held i uheld}

Det kan være svært at sige noget præcist om, hvorvidt omfanget, indholdet og rækkevidden af de kinesiske investeringer i udlandet vil fortsætte med at ekspandere i de kommende år, eller om den politiske ledelse i Kina på et tidspunkt vil slå bremsen i for yderligere global ekspansion.

Det er ikke sikkert, at de kinesiske statskontrollerede bankmyndigheder kan fortsætte deres hidtidige udlånsvirksomhed på samme måde og med samme intensitet $i$ al fremtid. Grundet mistanke om korruption og nepotisme har man i den senere tid taget initiativ til at iværksætte kontrolmekanismer og tilbagerulle nogle af de frihedsgrader, som kinesiske internationale investorer hidtil har nydt godt af. 
Måske er det alligevel held i uheld, at Danmark aldrig nogensinde fik tilbudt at hoppe på det kinesiske investeringslokomotiv.

Bør Danmark så helt undlade at pleje de politiske forbindelser til Kina?

$\mathrm{Nej}$, det giver al mulig god mening, at den danske udenrigstjeneste forsøger at opretholde gode forbindelser til alle de supermagter, der til enhver tid påvirker de grundlæggende parametre i international politik og økonomi.

I årene forud for Første Verdenskrig og i mellemkrigsårene lå det os på sinde at pleje vore relationer til især de europæiske stormagter. Under den kolde krig signalerede vi venskab med amerikanerne samtidig med, at vi forsikrede Sovjetunionen om, at vi ikke havde fjendtlige hensigter. I dag er også Kina blevet en stormagt, som naturligt skal indkalkuleres i dansk udenrigspolitik. Kinas plads i verdensøkonomien er mere end rigelig argumentation for, at Danmark skal opretholde en massiv diplomatisk tilstedeværelse i landet.

Argumentet i denne artikel er først og fremmest, at det tjener os godt at være realistiske i analysen af, hvad der er bestemmende for eksempelvis Kinas udenlandske investeringsaktivitet. Det lader ikke til, at gode politiske relationer til Kina kan ændre på det forhold, at kineserne frem for alt er gode købmænd.

De investerer præcis dér, hvor deres rationelle kalkule tilsiger, at de kan hente en gevinst. 